\title{
Spectroscopic Monitoring of Biodiesel Aging
}

\author{
Miķelis Svilans ${ }^{1}$, Aivars Blūms ${ }^{2}$, Rūta Kampare ${ }^{3},{ }^{1-3}$ Riga Technical University
}

\begin{abstract}
The suitability of absorption and fluorescence spectroscopy for monitoring biodiesel aging is assessed. Changes recorded in the UV/VIS and IR spectra during accelerated aging experiments are analysed with respect to corresponding changes in a selection of chemical and physical properties of biodiesel, namely, induction period, viscosity and acid number. A novel approach for evaluating fluorescence spectral data is presented. It is determined that fluorescence spectroscopy provides excellent sensitivity for detecting changes in biodiesel properties during early aging. Thus, a new sensitive method based on fluorescence for monitoring the quality of biodiesel is proposed.
\end{abstract}

Keywords: fluorescence, biodiesel, degradation, aging, optical absorption

\section{INTRODUCTION}

The environmental and economic advantages of biodiesel (BD) motor fuel, also known as B100, have been well documented and reviewed [1]. BD has the advantage of being more environmentally friendly than mineral diesel fuel, having low toxicity, sustainable supply, harmless degradation products, and being an important by-product of certain agricultural crops. However, compared to its fossil counterpart, a major disadvantage lies in its lower chemical stability, reflected in a higher rate of degradation due to aging, primarily by oxidation. A recent review of this problem [2] outlines some of the limitations of the Rancimat induction period as the aging criterion. More convenient and accurate methods for monitoring $\mathrm{BD}$ compliance with existing regulatory quality standards, such as EN 14214 [3] in the case of the European Union legislation, are of growing interest. To be of practical value, a method for monitoring BD quality should be convenient, rapid, and reliable. Ideally it should also be independent of producer and production process, but due to the wide variability of the biological feedstock chemical composition, method parameters may need product specific calibration.

\section{BACKGROUND}

Absorption and fluorescence are convenient spectroscopic techniques that have been widely used in characterizing vegetable oils $[4,5,6]$ and their aging properties [7, 7]. However, reports of their application to $\mathrm{BD}$ produced from these oils have been rather limited, notwithstanding that the chemistry involved is similar.

Spectroscopic methods are particularly attractive, as they can take advantage of the latest developments in semiconductor LED sources in the UV/VIS region, integrated photodetectors and fiberoptics to provide low-cost, reliable and rapid instrumentation.
However, these techniques have not been widely applied to monitor the oxidation state of BD.

In earlier research [9] it was demonstrated that the accelerated aging under severe conditions (high temperatures and extended periods of heating) produces substantial changes in the fluorescence spectrum of BD. However, to our knowledge a few reports have been published on how such spectral changes relate to standard specification parameters. Only recently spectrofluorimetry has been applied to $\mathrm{BD}$ accelerated oxidation studies, where PCA and PLS regression have been used to extract two principal components (latent parameters) from spectra correlated with Rancimat induction period measurements [10].

Since the specifications are extensive, a subset of parameters was selected as representative indicators, based on their sensitivity with respect to the progress of aging. Acid number, viscosity and induction period were considered to be among the first to exceed specifications with aging time.

Since BD is a complex mixture with a composition that can vary appreciably, it is generally impractical to isolate or separate the various components for the analysis. It does, however, contain natural fluorophores, which can be used as absorbance and fluorescence markers.

The organization of the paper is as follows: Section III introduces the type of samples used, the equipment used for their evaluation and the accelerated aging method details. In Section IV, the experimental results are presented. The results are discussed and interpreted in Section V; the conclusions are drawn in Section VI.

\section{EXPERIMENTAL SECTION}

\section{A. Samples}

The samples used included both untreated (no additives) and treated (with anti-oxidant additives) BD commercially produced in Latvia by four different producers from unrefined rapeseed oil: DGP - Daugavpils Area, BVT - Ventspils, MRZ and LTR - Jelgava Area. Only neat, i.e., undiluted samples were characterized to avoid possible solvent interaction artifacts.

\section{B. Accelerated Aging (Oxidation)}

Accelerated aging was performed by heating $500600 \mathrm{ml}$ of $\mathrm{BD}$ at $100{ }^{\circ} \mathrm{C}-120^{\circ} \mathrm{C}$ in a three-neck $1000 \mathrm{ml}$ flask, which was vented to ambient air through a reflux condenser (no forced air circulation) while stirring with a magnetic stirrer. The BD was sampled in $25-30 \mathrm{ml}$ quantities at 60 minute intervals, a total of 7-12 samples per batch. Since the oxidation process can be influenced by several factors and follow different paths [11], the sample was shielded from 
ambient light to reduce photoinduced oxidation, also avoiding contact with metal.

\section{Induction Period}

To determine oxidation stability, the induction period was measured using the test according to EN 14112 - Fat and Oil Derivates - Fatty Acid Methyl Esters (FAME) with a Rancimat Metrohm until the end-point was reached (the second derivative of the conductivity curve reaches a peak). The current standard EN 14214 [3] specifies that the induction period should be no less than 8 hours.

\section{IR Absorption}

Perkin-Elmer Spectrum 100 FTIR Spectrometer with an attenuated total reflection (ATR) attachment was used to measure IR absorption in the $650-4000 \mathrm{~cm}^{-1}$ wavenumber range with a $4.0 \mathrm{~cm}^{-1}$ resolution.

\section{E. UV/VIS Absorption}

Transmission absorption spectra were determined with a Perkin-Elmer Lambda 35 Spectrometer in the 250-1100 nm wavelength range in a $10 \mathrm{~mm}$ quartz cuvette.

\section{F. UV/VIS Fluorescence}

Total fluorescence excitation-emission matrix (EEM) spectra were acquired using a Perkin-Elmer LS-45 Fluorescence Spectrometer in a $10 \mathrm{~mm}$ quartz cuvette with 10 $\mathrm{nm}$ resolution. Typically, the excitation wavelengths of 250 $800 \mathrm{~nm}$ in $5 \mathrm{~nm}$ steps were recorded with emission wavelengths $200-900 \mathrm{~nm}$ in $0.5 \mathrm{~nm}$ steps. The standard instrument geometry is right-angled, which was modified for some tests to enable front-face spectra to be measured.

\section{RESULTS}

\section{A. Induction Period}

The measured Rancimat conductivity curves for BD samples aged at $120{ }^{\circ} \mathrm{C}$ for different times up to 7 hours are shown in Fig. 1.

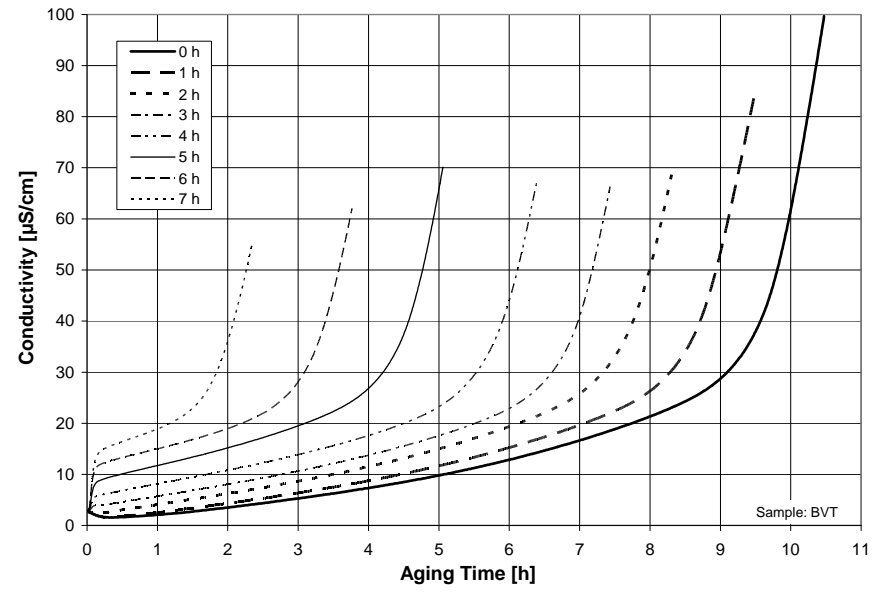

Fig. 1. Rancimat curves of BD sample 'BVT' containing anti-oxidant for various aging times from 0 to 7 hours at $120^{\circ} \mathrm{C}$

The induction period deduced mathematically from these curves by the equipment manufacturer's software is plotted against aging time in Fig. 2. It is seen to decrease monotonically with increasing aging time, exceeding the EN 14214 specification after about 2 hours of accelerated aging in the case of a BVT sample containing anti-oxidants.

\section{B. Acid Number}

The acid number increased linearly with aging time as can be seen in Fig. 3. For the BVT sample containing antioxidants, the specification value of $0.5 \mathrm{mg} \mathrm{KOH} / \mathrm{g}$ as determined by EN 14104 was exceeded after 6 hours of accelerated aging.

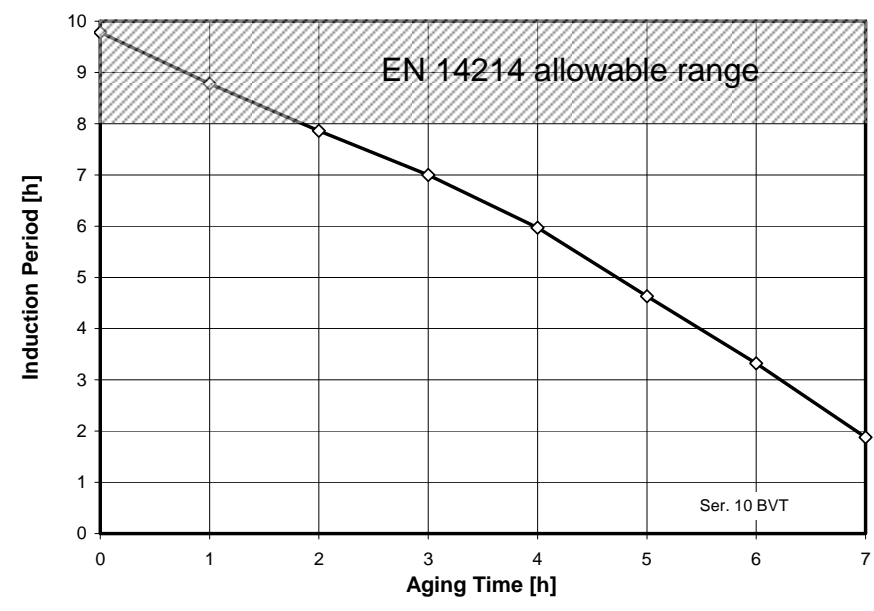

Fig. 2. Induction period versus aging time of BD sample 'BVT' indicating an allowable range according to the EN14112 Standard

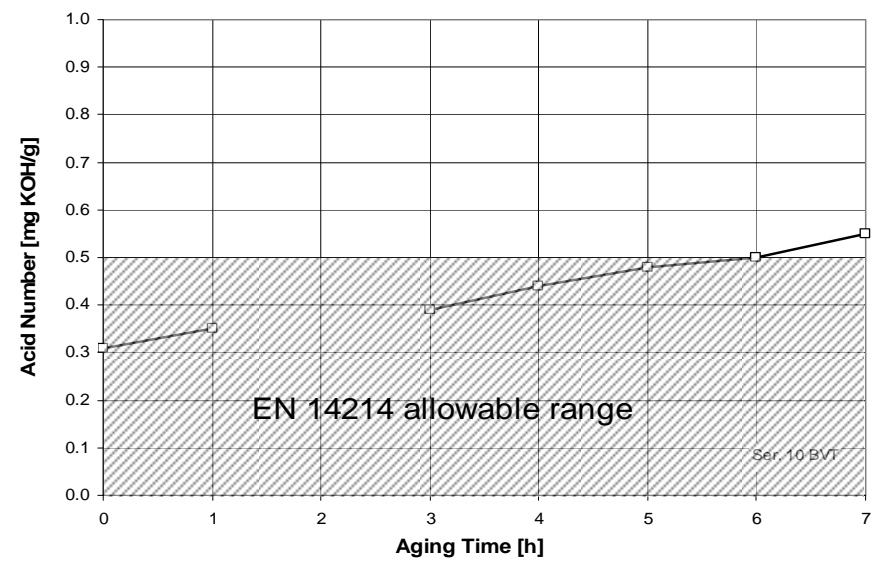

Fig. 3. Acid number versus aging time of BD sample 'BVT' indicating an allowable range according to the EN14104 Standard

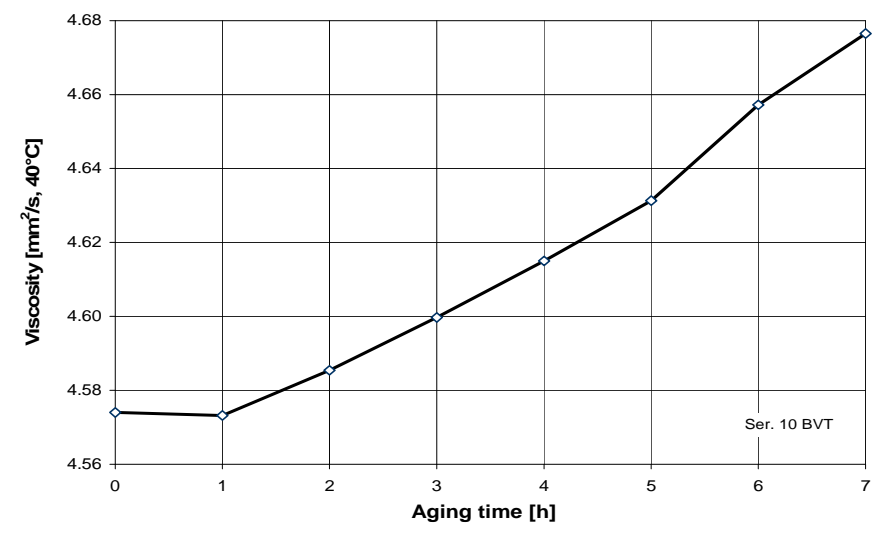

Fig. 4. Viscosity versus aging time of BD sample 'BVT' 


\section{Viscosity}

Fig. 4 shows the viscosity of the BVT sample containing anti-oxidants increasing approximately linearly with aging time. In this case, the EN IS0 3104 specification, 3.5-5.0 $\mathrm{mm}^{2} / \mathrm{s}$ at $40^{\circ} \mathrm{C}$, was not exceeded (Fig. 5).

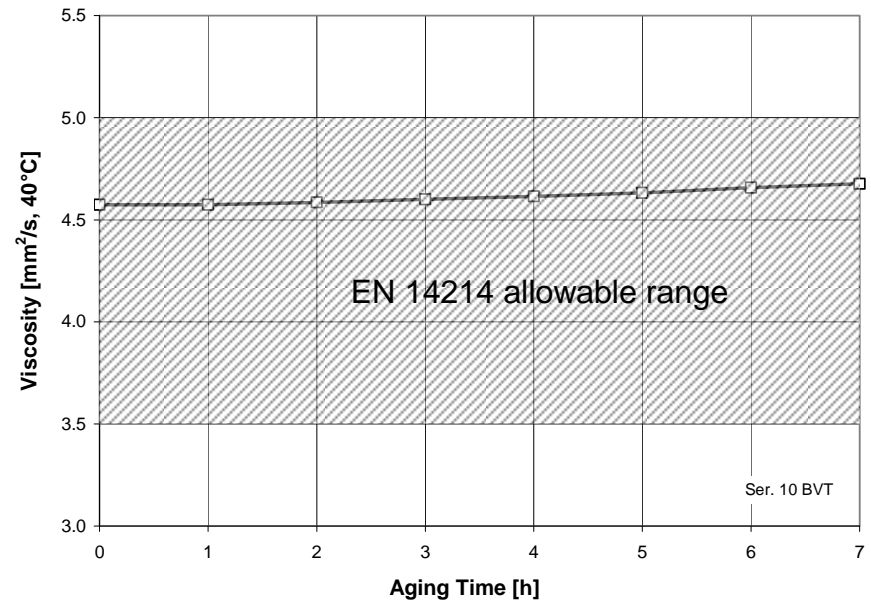

Fig. 5. Viscosity versus heating time of BD sample 'BVT' indicating an allowable range under the EN ISO 3104 Standard

\section{FT-IR Absorption}

A typical set of FT-IR ATR spectra is shown in Fig. 6 with aging times from 0 to 9 hours at $100{ }^{\circ} \mathrm{C}$ for a MRZ sample without anti-oxidants. Some absorption variation with heating time can be observed in the $1197,1216,1230$, and $1364 \mathrm{~cm}^{-1}$ bands; however, no monotonic dependence was observed. A peak at $1742 \mathrm{~cm}^{-1}$ (not shown here) exhibited similar behaviour.

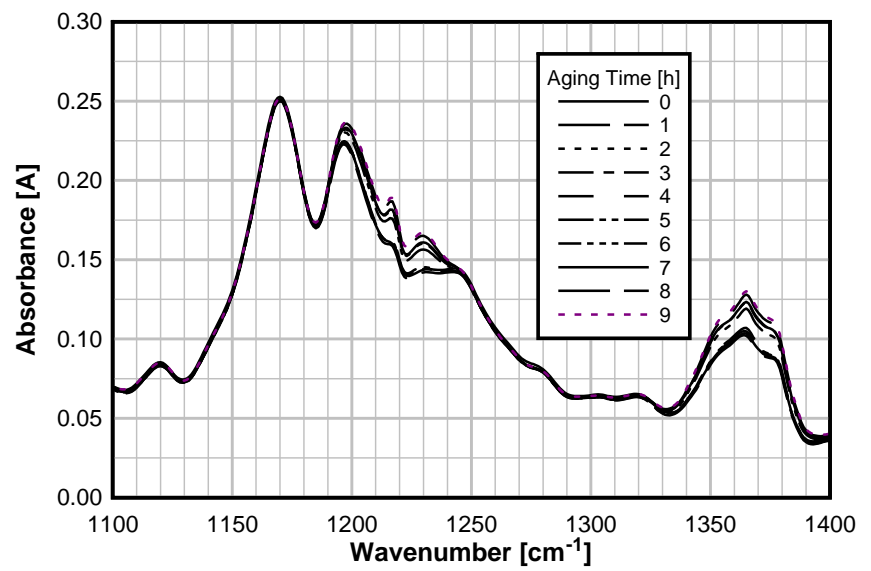

Fig. 6. FT-IR spectra as a function of aging time of BD sample 'MRZ'

\section{E. UV/VIS Absorption}

All of the neat unrefined samples measured in a $10 \mathrm{~mm}$ cuvette exhibited a high absorption at wavelengths below approximately $500 \mathrm{~nm}$ for all heating times. This is similar to the reported behaviour of BD blends [11]. Fig. 7 displays the results for samples from three different producers - (a) BD containing anti-oxidants, aged at $100{ }^{\circ} \mathrm{C}$, (b) and (c) BD with no anti-oxidant additives aged at $110^{\circ} \mathrm{C}$.

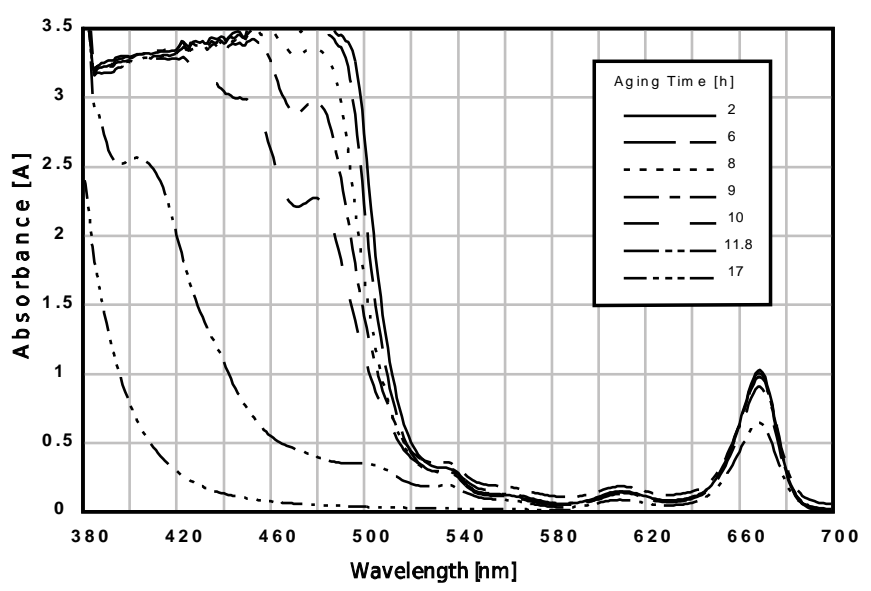

(a)

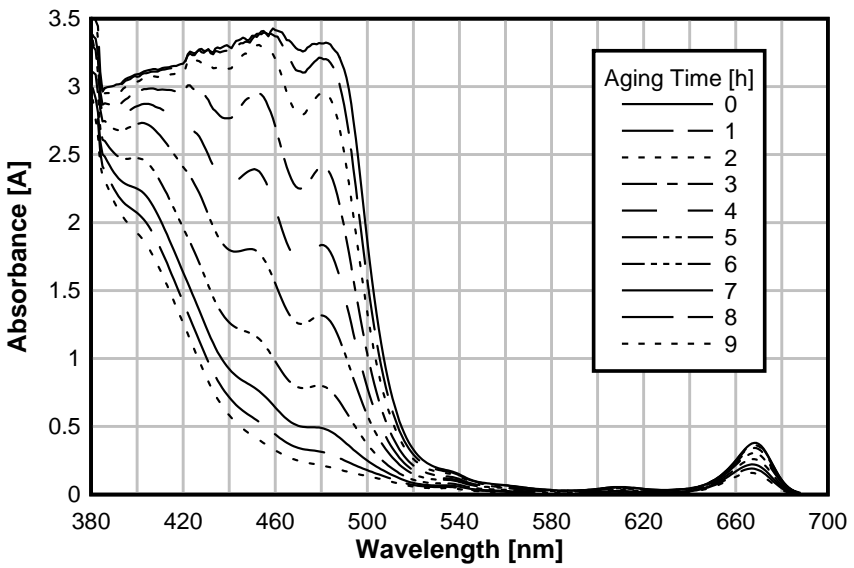

(b)

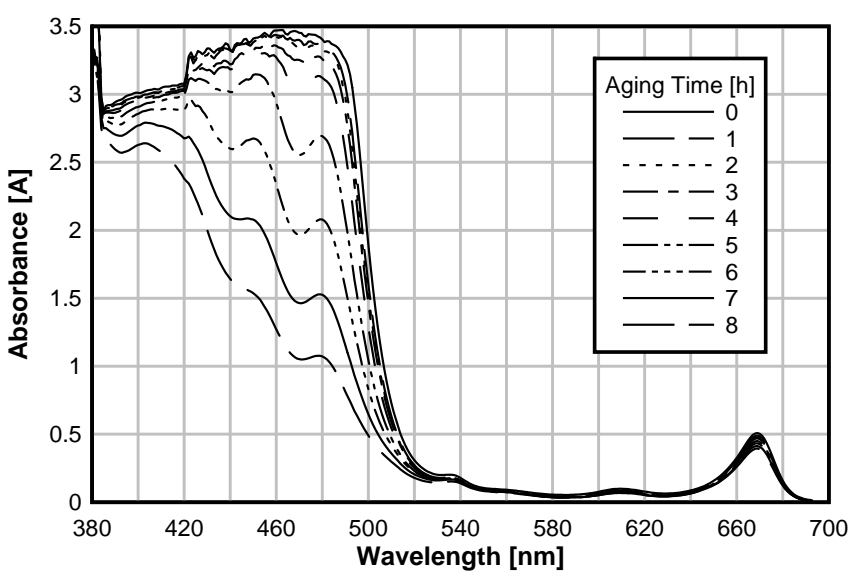

(C)

Fig. 7. UV/VIS spectra as a function of aging time for different BD samples (a) 'BVT' containing anti-oxidant additives (note aging times!); (b) 'MRZ', no anti-oxidant additives; and (c) 'LTR', no anti-oxidant additives

\section{F. UV/VIS Fluorescence}

Typical fluorescence emission spectra for aging times from 0 to 7 hours with two different excitation wavelengths, $320 \mathrm{~nm}$ and $440 \mathrm{~nm}$, are presented in Figs. 8(a) and (b), respectively, using a 'MRZ' sample without anti-oxidant additives as an example. 


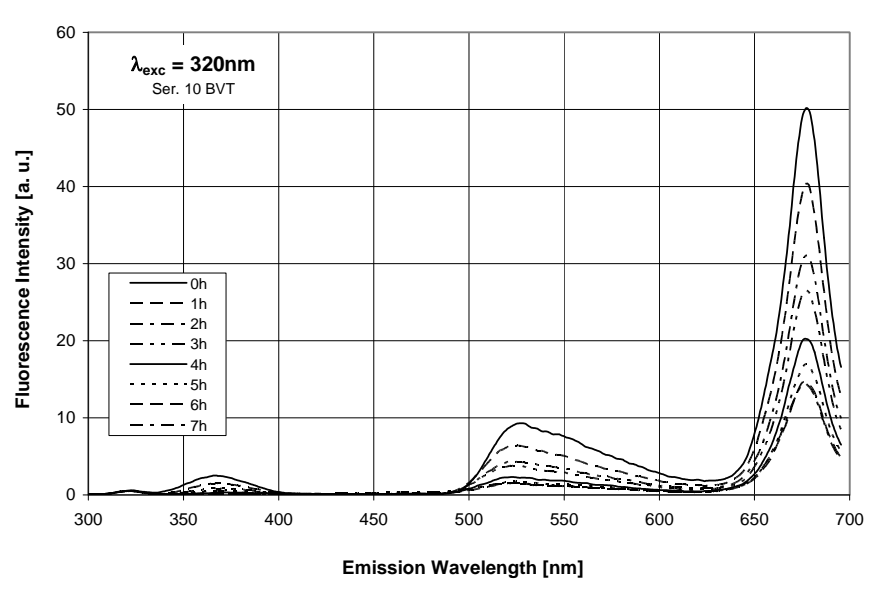

(a)

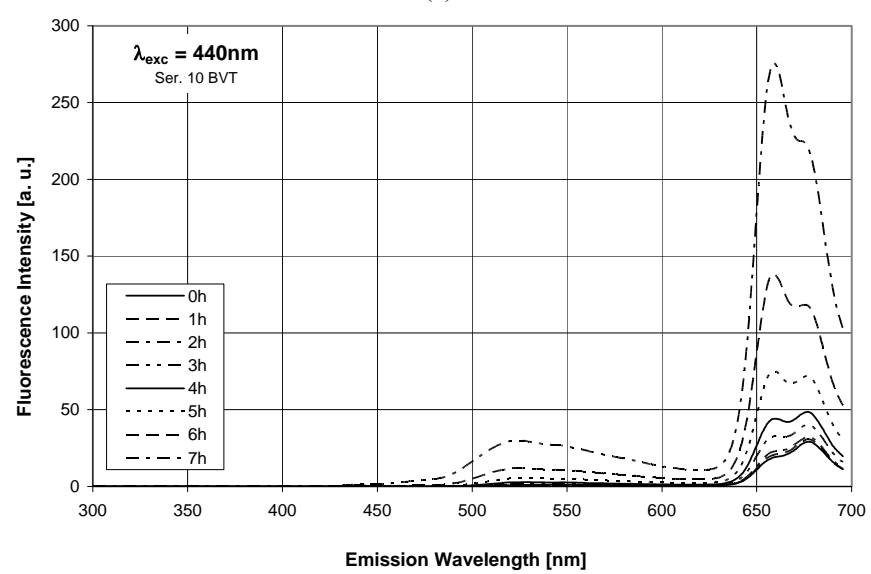

(b)

Fig. 8. Emission spectra of a BD sample on the customary linear intensity scale for various aging times with $\lambda_{\text {exc }}$ (a) $320 \mathrm{~nm}$ and (b) $440 \mathrm{~nm}$

\section{DISCUSSION}

Results show that under the aging conditions used here, Induction Period (Fig. 2), Acid Number (Fig. 3) and Viscosity (Fig. 4) of biodiesel (BD) follow a predictable trend. This permits the aging time to be used as a convenient common parameter when evaluating the spectral response.

In the FT-IR spectra, using Fig. 6 as a typical example, the changes in absorption were not consistently monotonic with aging time. A possible explanation could be the creation and destruction of transient oxidation by-products such as peroxides. Similar spectral variability in vegetable oils (feedstock for BD) has been ascribed to uncontrolled amounts of $\mathrm{OH}$-containing components (alcohols, free fatty acids and water) and variations in triglyceride composition, which may cause interference due to overlapping absorption bands [12]. Although these uncertainties may be overcome by chemical methods, for instance, adding TBHP and applying PLS chemometric techniques, or implementation of several spectral references [13], the complexity of such FT-IR analysis was seen as limiting its suitability for the purposes of this study.

Absorption in transmission in the UV/VIS range, on the other hand, exhibited a very pronounced trend with aging time, as can be seen in Figs. 7(a)-(c). Absorption levels decreased with aging time for all samples in the $380-540 \mathrm{~nm}$ range, the most pronounced changes being evident around 390-490 nm.

The structure of the spectra suggests that the absorption is dominated by four bands with peaks centred about 402, 424, 450 and $480 \mathrm{~nm}$, the last one changing most rapidly with aging time. With the available spectrometer resolution $(10 \mathrm{~nm})$ it was not possible to experimentally separate the overlapping bands; however, mathematical techniques were not attempted.

The intensity of the observed absorption peak of near $674 \mathrm{~nm}$, generally attributed to chlorophyll, exhibited a consistent dependence on aging time, but its magnitude varied considerably from producer to producer and batch to batch, so it was not considered sufficiently reliable for use in a robust monitoring method.

While the potential of transmission absorption as a BD quality monitoring method is recognized, the above overlapping bands would need to be resolved before its utility can be established.

In the fluorescence emission spectra for a typical BD sample ('MRZ' aged at $120^{\circ} \mathrm{C}$ ) shown previously, opposing trends with aging time are apparent, decreasing and increasing in intensity with $\lambda_{\text {exc }}=320 \mathrm{~nm}$ (Fig. 8(a) ) and $\lambda_{\text {exc }}=440 \mathrm{~nm}$ (Fig. 8(b)), respectively, over large sections of the spectrum. How well these changes correlate with aging time is not immediately obvious from the spectra, however.

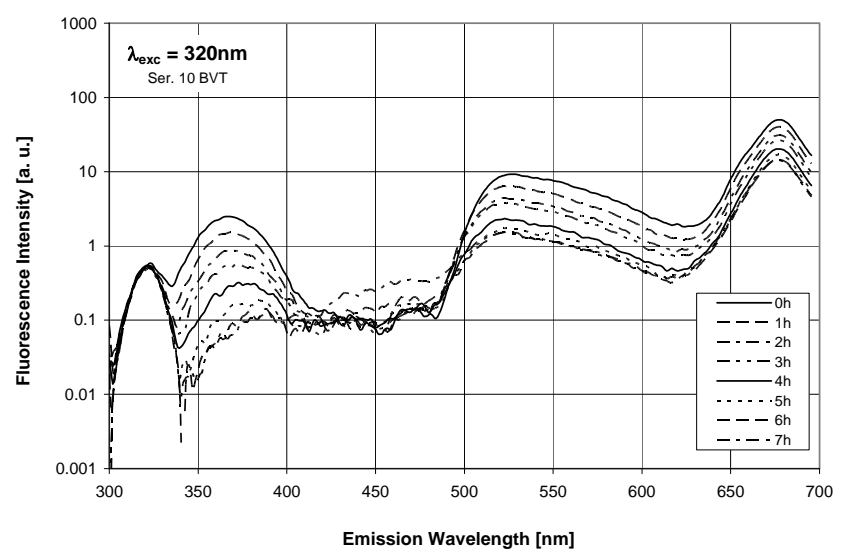

(a)

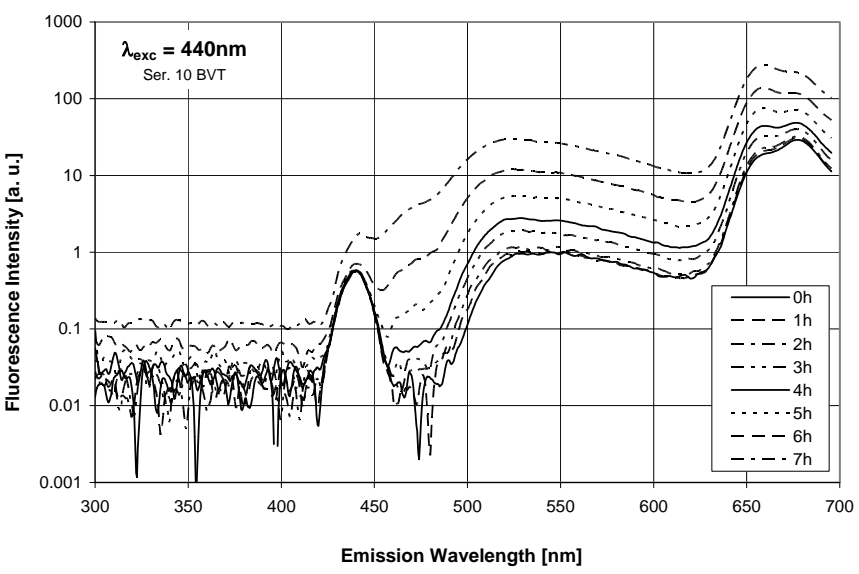

(b)

Fig. 9. Emission spectra of a BD sample on a logarithmic fluorescence intensity scale for various aging times with $\lambda_{\mathrm{exc}}$ (a) $320 \mathrm{~nm}$ and (b) $440 \mathrm{~nm}$ 
Inspecting the same fluorescence intensity data on a logarithmic scale (Figs. 9(a) and 9(b), respectively) reveals extensive spectral regions that are similar in shape. Their intensity varies with aging over a wide range, often more than by an order of magnitude. Furthermore, the trend with aging is much more readily apparent, particularly in the range from about $520 \mathrm{~nm}$ to $620 \mathrm{~nm}$.

In this range the fluorescence intensity decreases with aging time for the case of shorter excitation wavelengths, such as $320 \mathrm{~nm}$ in Fig. 9(a), while at longer excitation wavelengths, such as $440 \mathrm{~nm}$ in Fig. 9(b), the trend is reversed. This is more clearly evident in the excitation spectra taken at an emission wavelength of $550 \mathrm{~nm}$ for aging times from 0 to 7 hours, as shown in Fig. 10.

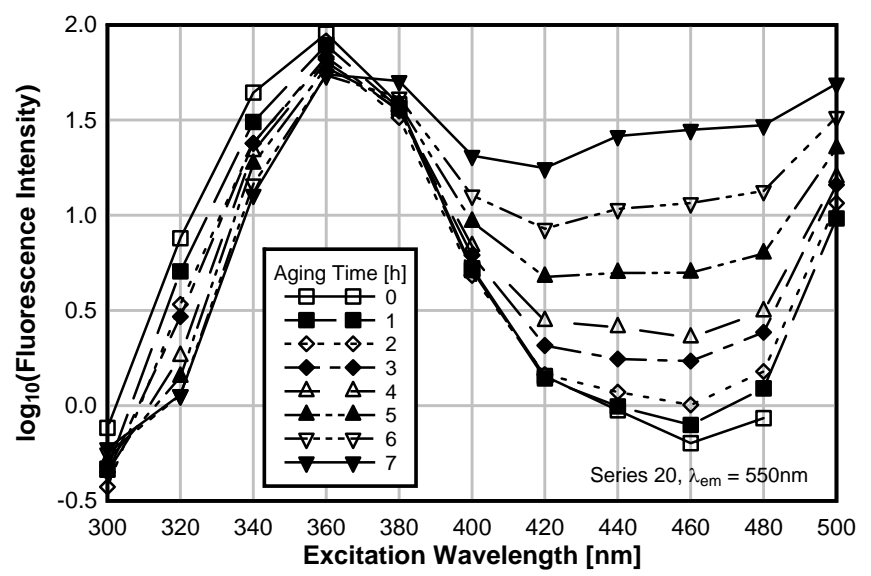

Fig. 10. Excitation spectra of a BD sample on a logarithmic fluorescence intensity scale with $\lambda_{\text {em }} 550 \mathrm{~nm}$ for different aging times

The opposing trends are illustrated in Fig. 11, where the fluorescence intensity at $550 \mathrm{~nm}$ is plotted on a logarithmic scale as a function of aging time for two different excitation wavelengths (320 and $440 \mathrm{~nm}$ ).

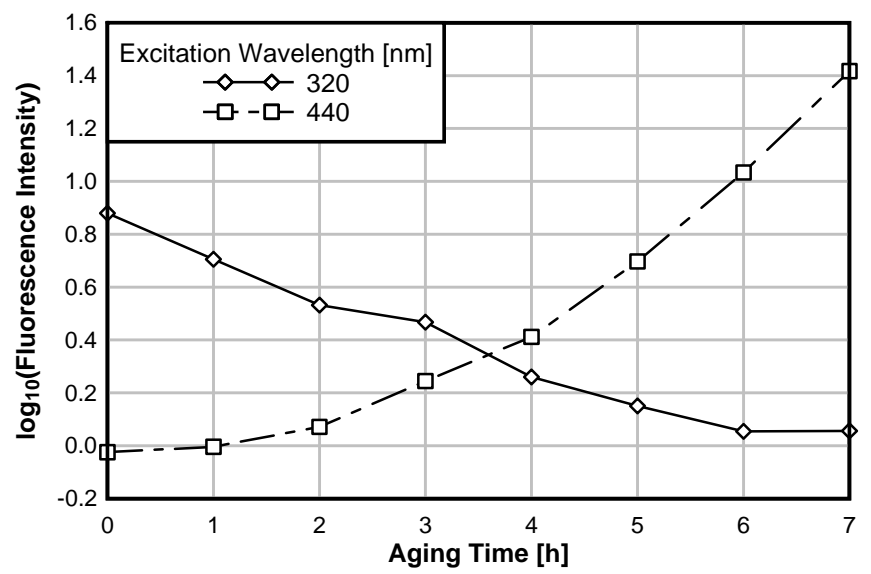

Fig. 11. Logarithm of fluorescence emission intensity at $550 \mathrm{~nm}$ as a function of aging time of a BD sample for $320 \mathrm{~nm}$ and $440 \mathrm{~nm}$ excitation wavelengths

By taking the ratio of the two curves in Fig. 11 in order to remove baseline dependency, a sensitive indicator of aging progress results, changing by more than two orders of magnitude for aging times up to 7 hours, as seen in Fig. 12.
The emission wavelength of $550 \mathrm{~nm}$ chosen here as an example is not unique. Other wavelengths in the approximate range from $520 \mathrm{~nm}$ to $620 \mathrm{~nm}$ exhibit similar behaviour.

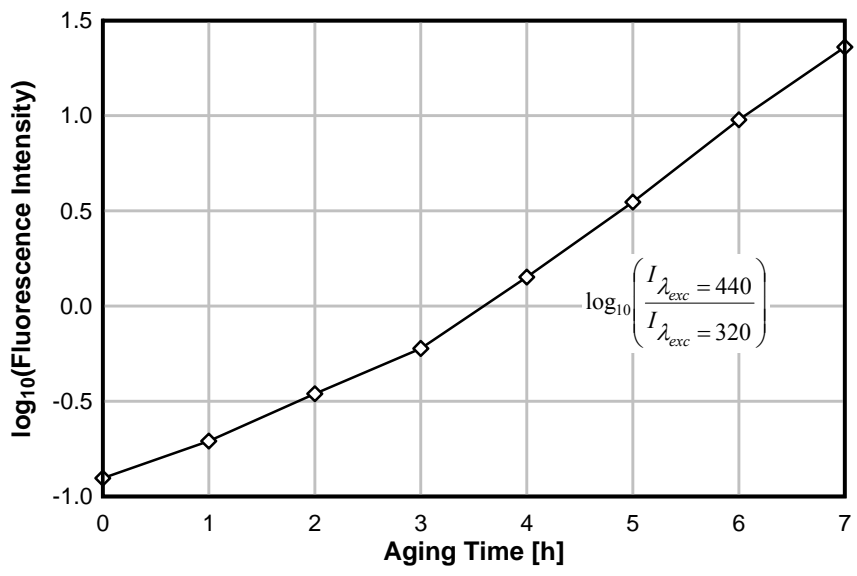

Fig. 12. Logarithm of the ratio of fluorescence intensity at $550 \mathrm{~nm}$ excited with $440 \mathrm{~nm}$ to $320 \mathrm{~nm}$ as a function of aging time at $120^{\circ} \mathrm{C}$ for BD sample 'MRZ'

From Figs. 9(a) and (b) a pronounced increase in fluorescence intensity is evident as the emission wavelength increases above 500nm. This corresponds to the spectral absorption edge seen in (Figs. 7(a)-(c)), which indicates that the primary inner filter effect [Holland 14] plays a significant role. The effect is an artifact of the right-angle geometry used in fluorescence measurements on high optical density liquids, such as the $\mathrm{BD}$, in this case for excitation wavelengths below $500 \mathrm{~nm}$. A linear decrease in the concentration of absorbing species with aging time is, thus, expected to produce a logarithmic increase in the inner excitation intensity, which in turn produces a logarithmic increase in the emission intensity.

In principle, the $\mathrm{BD}$ aging progress could be simply monitored with two separate excitation sources (light-emitting diodes, for instance) and a single photodetector with a suitable passband filter. The combination of these components with a microcontroller would allow the construction of an inexpensive but effective monitoring instrument without the need for complex analysis methods, such as PCA, PLS and the like, or the acquisition of fluorescence spectra.

\section{CONCLUSIONS}

In this study, a novel approach to evaluating fluorescence spectra has been presented. By plotting the UV-visible spectra on a logarithmic intensity scale, several trends with aging are revealed that would otherwise not become readily apparent.

Thus, a new sensitive indicator of accelerated aging progress has been proposed based on the fluorescence intensity of neat biodiesel, which has been subjected to aging under dark conditions in still air. The indicator value is derived from the ratio of $550 \mathrm{~nm}$ emission intensity for two different excitation wavelengths, typically $440 \mathrm{~nm}$ to $320 \mathrm{~nm}$ for the samples studied here. It is proposed that the primary inner filter effect arising from the right-angle geometry used, plays a significant role. 
The novel sensitive indicator appears to be a suitable basis for a robust spectroscopic method for the monitoring of biodiesel aging or oxidation. This study also suggests that the logarithm of the intensity should be considered in preference to intensity for establishing correlations in chemometric analyses when the right-angled fluorescence geometry is used.

\section{ACKNOWLEDGEMENTS}

The research has been supported by the ESF Project "Scientific Group Supporting Latvian Activities of the European Strategic Energy Technology Plan", No.1DP/1.1.1.2.0/ 09/APIA/ VIAA/027. The visiting author (M. S.) wishes to thank Prof. Valdis Kampars, Director, for providing research facilities at the Institute of Applied Chemistry, RTU. The assistance of Kristīne Lazdoviča, Spectroscopy Laboratory, Institute of Applied Chemistry in facilitating spectral measurements is acknowledged. Thanks are extended to the biodiesel producers Mamas D Ltd., Mežrozìte Ltd., BioVenta Ltd., LatRaps Ltd. for supplying the samples.

\section{REFERENCES}

1. Demirbas, A. Political, economic and environmental impacts of biofuels: A review. Applied Energy, 2009, Vol. 86, p. S108-S117. http://dx.doi.org/10.1016/j.apenergy.2009.04.036

2. Pullen, J., Saeed, K. An overview of biodiesel oxidation stability. Renewable and Sustainable Energy Reviews, 2012, Vol. 16, p. 59245950. http://dx.doi.org/10.1016/j.rser.2012.06.024

3. European Committee for Standardization (CEN). EN 14214 Automotive fuels - diesel - fatty acid methyl esters (FAMEs) requirements and test methods. CEN, Brussels, Belgium.

4. Sikorska, E., Romaniuk, A., Khmelinskii, I. V., Herance, R., Bourdelande, J. L., Sikorski, M., J. Koziol. Characterization of Edible Oils Using Total Luminescence Spectroscopy. Journal of Fluorescence, 2004, Vol. $14, \quad$ p. http://dx.doi.org/10.1023/B:JOFL.0000014656.75245.62

5. Kongbonga, Y. G. M., Ghalila,H., Onana, M. B., Majdi, Y., Lakhdar, Z. B., Mezlini, H., Sevestre-Ghalila, S. Characterization of Vegetable Oils by Fluorescence Spectroscopy. Food and Nutrition, 2012, Vol. 2, p. 692-699. http://dx.doi.org/10.4236/fns.2011.27095

6. Guimet, F., Boqué, R., \& Ferré, J. Application of non-negative matrix factorization combined with Fisher's linear discriminant analysis for classification of olive oil excitation-emission fluorescence spectra.. Chemometrics and intelligent laboratory systems, 2006, Vol. 81, p. 94-106. http://dx.doi.org/10.1016/j.chemolab.2005.10.003

7. Kyriakidis, N. B., Paulos Skarkalis, P. Fluorescence Spectra Measurement of Olive Oil and Other Vegetable Oils. Journal of AOAC International, 2000, Vol. 83, p. 1435-1439.

8. Sikorska, E., Khmelinskii, I. V., Sikorski, M., Caponio, F., Bilancia, M. T., Pasqualone, A., \& Gomes, T. Fluorescence spectroscopy in monitoring of extra virgin olive oil during storage. International Journal of Food Science \& Technology, 2008, Vol. 43, p. 52-61. http://dx.doi.org/10.1111/j.1365-2621.2006.01384.x

9. Kampars, V., Ratjeva, S. Fluorescence Spectroscopy Investigation of Degradation of Rapeseed Oil Methyl Esters. RTU Zinātniskie raksti Materiālzinātne un lietišksā ķīmija, 2005, Vol. 10, p. 59-64.

10. Meira, M., Quintella, C. M., Tanajura, A. D. S., Da Silva, H. R. G., Fernando, J. D., da Costa Neto, P. R., Pepe, I. M., Santos, M. A.,
Nascimento, L. L. Determination of the oxidation stability of biodiesel and oils by spectrofluorimetry and multivariate calibration. Talanta, 2011, Vol. 85, p. 430-434. http://dx.doi.org/10.1016/j.talanta.2011.04.002

11. Zawadzki, A., Shrestha, D. S. Biodiesel Feedstock and Blend Level Sensing Using Visible Light Spectra and Neural Network. Transactions of the ASABE, 2009, Vol. 52, p. 539-542.

12. Van de Voort, F. R., Ismail, A. A., Sedman, J., Dubois, J., Nicodemo, T. The Determination of Peroxide Value by Fourier Transform Infrared Spectroscopy. Journal of the American Oil Chemists' Society, 1994, Vol. 71, p. 921-926.

13. Van de Voort, F. R., Ismail, A. A., Sedman, J., Emo, G. Monitoring the Oxidation of Edible Oils by Fourier Transform Infrared Spectroscopy. Journal of the American Oil Chemists' Society, 1994, Vol. 71, p. 243253.

14. Holland, J. F., Teets, R. E., Kelly, P. M., \& Timnick, A., Correction of right-angle fluorescence measurements for the absorption of excitation radiation, Analytical Chemistry, 1977, Vol. 49, p. 706-710. http://dx.doi.org/10.1021/ac50014a011

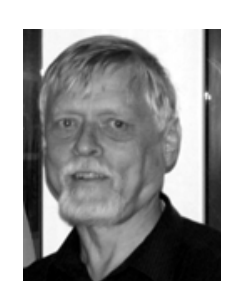

Miķelis Svilans, Dr.-Ing. in III-V Compound Semiconductor Electronics, received from the RWTH Aachen University in 1980. Previously obtained M. Eng. Sc. in Electronics (1975), B.E. (Hons.) in Electrical Engineering (1973) and B.Sc. (Computer Science) (1972) from the University of Adelaide.

With more than 20 years of experience in the fibre-optic telecommunications industry, he joined the Institute of Applied Chemistry at RTU as a Lead Researcher on a three year research term within the framework of the ESF Project "Scientific Group Supporting Latvian Activities of the European Strategic Energy Technology Plan”. Main research interests are photonics and spectroscopy.

E-mail: mikelis@ktf.rtu.lv

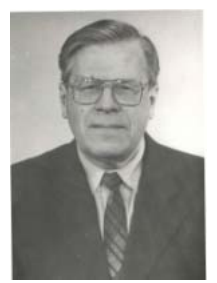

Aivars Blūms, Dr.chem., Leading researcher at the Institute of Applied Chemistry, Riga Technical University.

He obtained the degree of Candidate of Sciences in Inorganic Chemistry in 1967 from Riga Politechnical Institute; Dr.chem in 1992.

Previous and current research interests include inorganic peroxide compounds, metal corrosion, biodiesel synthesis and properties.

Address: Institute of Applied Chemistry, Riga Technical University, 14/24 Azenes Str., Riga, LV-1048, Latvia

E-mail: aivars@ktf.rtu.lv

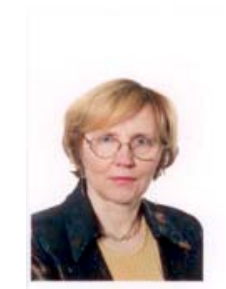

Rūta Kampare, Master of Chemical Sciences and the fifth level professional education. Education: 19661971, Riga Polytechnical Institute, Faculty of Chemistry. Experience: 1971-1973, Senior Laboratory Assistant at the Department of Organic Chemistry; 1973-1995, Senior Engineer at the Department of Organic Chemistry; 1995-2006 Quality Inspector at Latvijas Balzams JSC; since 2007 - Researcher at the Institute of Applied Chemistry (Riga Technical University). Research: studies of the quality of biodiesel, its raw materials and by-products

Address: 14/24Azenes Str., Riga, LV-1048, Latvia

Phone: +37129443106

E-mail: ruta@ktf.rtu.lv

\section{Miķelis Svilans, Aivars Blūms, Rūta Kampare. Spektroskopiska biodīzel̦a novecošanās kontrole}

Biodīzelis ir atjaunojama enerǵijas forma, kurai tiek pievērsta liela uzmanība, bet to no plašăkas ieviešanas un pielietošanas attur tendence ātrāk novecot jeb oksidēties, salīdzinot ar minerāldegvielām. Tiek meklēti ātri un ērti veidi, kā noteikt biodīzeḷa derīgumu. Eksperimentāli parādīts, ka absorbcijas un fluorescences spektroskopija ir piemērotas metode šādai biodīzel̦a novecošanās kontrolei. Dažādu Latvijas ražotāju biodīzeḷa paraugi tika pakḷauti paātrinātam oksidēšanās procesam, karsējot biodīzeli tumsā bez piespiedu gaisa cirkulācijas $110^{\circ} \mathrm{C}-120^{\circ} \mathrm{C}$ temperatūrā. Periodiski noṇemtajiem paraugiem tika mērīi absorbcijas un fluorescences spektri, kā arī noteiktas tādas fizikāli ķ̄imiskās īpašības 
kā indukcijas periods, viskozitāte un skābes skaitlis. Atrastas kopsakarības starp pārmaiṇām UV/VIS un IR spektros paātrinātas novecošanās laikā un minētajām fizikāli ķīmiskajām īpašībām, salīdzinot tās ar pastāvošā biodīzeḷa standarta prasībām. Konstatētas spektrālās joslas, kurās, oksidēšanās laikam palielinoties, notiek sistemātiskas pārmaiņas absorbcijas un fluorescences spektros, Fluorescenci ierosinot ar īsāka viḷnu garuma starojumu (apm. 320 - 360 nm), izstarojuma intensitāte krītas, bet, ja viḷnu garums ir lielāks (apm. 400 - 500 nm), tā pieaug. Izmantojot šīs pretējās tendences, izveidota inovatīva pieeja fluorescences spektrālo datu izvērtēšanai, kura dod iespēju ar izcilu jutīgumu konstatēt biodīzel̦a oksidēšanos un ar to saistîtās kvalitātes izmaiņas. Līdz ar to tiek piedāvāta jauna, jutīga, uz fluorescenci pamatota, metode biodīzeḷa kvalitātes kontrolēšanai.

\section{Микелис Свиланс, Айварс Блумс, Рута Кампаре. Спектроскопический контроль старения биодизеля.}

Биодизель является обновляемой формой энергии, к нему привлечено большое внимание, но более широкому применению этого топлива мешает тенденция биодизеля быстро стареть или окисляться, по сравнению с минеральными топливами. В настоящее время идет поиск новых, быстропроводимых и чувствительных методов определения пригодности биодизеля. В работе оценивается пригодность абсорбционной и флуоресцентной спектроскопии для контроля старения или окисления биодизеля. Образцы биодизеля разных производителей Латвии подвергались ускоренному процессу окисления нагреванием в темноте без принудительной циркуляции воздуха при температуре $110^{\circ} \mathrm{C}-120^{\circ} \mathrm{C}$. Периодически отобранным образцам биодизеля измеряли спектры поглощения и флуоресценции, а также определяли период индукции, вязкость и кислотное число. Показана взаимосвязь между изменениями в УФ, видимых и ИК спектрах во время ускоренного старения и указанными физико-химическими свойствами, которые сравнивались с требованиями существующего стандарта биодизеля. Обнаружены спектральные диапазоны, в которых с увеличением времени окисления при возбуждении более корокими волнами (около 320 - 360 нм), интенсивность излучения флуоресценции уменьшается, а при возбуждении более длиними волнами (около 400 - 500 нм), увеличивается. Используя эти противоположные тенденции, создан инновативный подход для оценки данных флуоресцентного спектрального анализа, который позволяет с высокой чувствительностью определить изменения свойств биодизеля в результате окисления. Таким образом, предлагается новый, чувствительный метод на основе флуоресценции для контроля качества биодизельного топлива. 